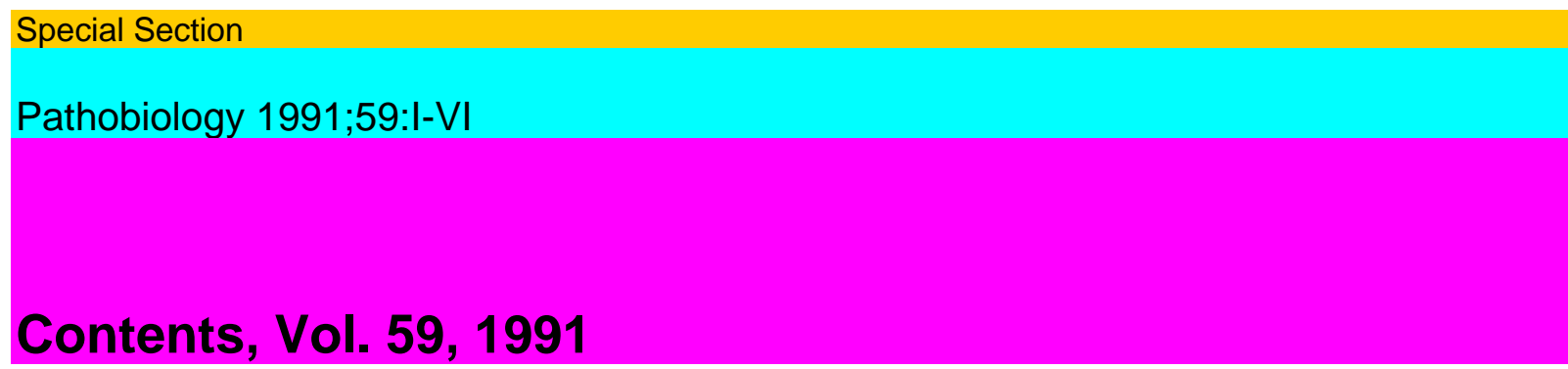

Founded 1938 as 'Schweizerische Zeitschrift für allgemeine Pathologie und Bakteriologie' by A. v. Albertini, A. Grumbach and H. Mooser, continued as 'Pathologia et Microbiologia' (19601975) and 'Experimental Cell Biology' (1976-1989); incorporating 'Pathology and Immunopathology Research', founded 1982 as 'Survey and Synthesis of Pathology Research' by J. Cruse and R.E. Lewis

Editor-in-Chief

J.M. Cruse, Jackson, Miss.

Deputy Editor-in-Chief

R.E. Lewis, Jr., Jackson, Miss.

Senior Editors

M.I. Greene, Philadelphia, Pa. G.V. Sherbet, Newcastle-upon-Tyne C. Sorg, Münster

Editorial Board

P. Bonventre, Cincinnati, Ohio

R.B. Colvin, Boston, Mass.

E. Farber, Toronto

S.D. Greenberg, Houston, Tex.

I.R. Hart, London

P.U. Heitz, Zurich

K. Hirokawa, Tokyo

A.B. Jenson, Washington, D.C.

W.W. Johnson, Jackson, Miss.

J. Kant, Philadelphia, Pa.

D. Kaufman, Chapel Hill, N.C.

J.D. Kemp, Iowa City, Iowa

R.L. Kradin, Boston, Mass.

S.L. Kunkel, Ann Arbor, Mich.

M.S. Lakshmi, Newcastle-upon-Tyne

R.G. Lynch, Iowa City, Iowa

C.J. Marshall, London

G.E. Marti, Bethesda, Md.

W.J. Mergner, Washington, D.C.

P.M. Newberne, Boston, Mass.

G.L. Nicolson, Houston, Tex.

R.M. O'Neal, Jackson, Miss.

J.S. Pober, Boston, Mass.

M. Potter, Bethesda, Md.

P.A. Riley, London

N.R. Rose, Baltimore, Md.

H.S. Rosenberg, Houston, Tex. 
A. Rostami, Philadelphia, Pa.

A.P. Sanfilippo, Durham, N.C.

T. Shirai, Tokyo

H. Shulman, Seattle, Wash.

L. Silberstein, Philadelphia, Pa.

A. Sirica, Richmond, Va.

D. Tarin, Oxford

F.B. Taylor, Jr., Oklahoma City, Okla.

B.F. Trump, Baltimore, Md.

R. Ulevitch, La Jolla, Calif.

P.A. Ward, Ann Arbor, Mich.

T. Yoshiki, Sapporo

KAIUiER

S. Karger - Medical and Scientific Publishers

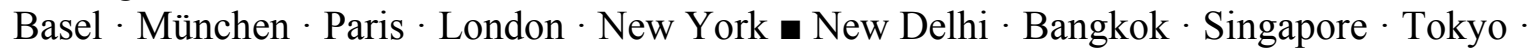

Sydney

Drug Dosage

The authors and the publisher have exerted every effort to ensure that drug selection and dosage set forth in this text are in accord with current recommendations and practice at the time of publication. However, in view of ongoing research, changes in government regulations, and the constant flow of information relating to drug therapy and drug reactions, the reader is urged to check the package insert for each drug for any change in indications and dosage and for added warnings and precautions. This is particularly important when the recommended agent is a new and/or infrequently employed drug.

All rights reserved.

No part of this publication may be translated into other languages, reproduced or utilized in any form or by any means, electronic or mechanical, including photocopying, recording, microcopying, or by any information storage and retrieval system, without permission in writing from the publisher or, in the case of photocopying, direct payment of a specified fee to the Copyright Clearance Center (see 'Information for Readers and Subscribers').

(C) Copyright 1991 by S. Karger AG, P.O. Box, CH- 4009 Basel (Switzerland) Printed in Switzerland on acid-free paper by Thür AG Offsetdruck, Pratteln

Contents Vol. 59,1991

No. 1

The Ferrobiology of Neoplasia, Symposium (Part I)

Introduction

Kemp, J.D 1

Targeting Iron-Dependent DNA Synthesis with Gallium and

Transferrin-Gallium

Chitambar, C.R.; Narasimhan, J 3

Regulation of Transfemn Receptor Expression and Control of

Cell Growth

Neckers, L.M 11

Comparison of Transfemn Receptors, Iron Content and Iso-

ferritin Profile in Normal and Malignant Human Breast 


\section{Cell Lines}

Shterman, N.; Kupfer, B.; Moroz, C 19

Qualitative Functional Deficiency of Affinity-Purified Lacto-

ferrin from Neutrophils of Patients with Chronic Myeloge-

nous Leukemia, and Lactoferrin/H-Ferritin-Cell Interac

tions in a Patient with Lactoferrin-Deficiency with Normal

Numbers of Circulating Leukocytes

Broxmeyer, H.E.; Bicknell, D.C.; Cooper, S.; Sledge, G,

Jr.; Williams, D.E.; McGuire, W.A.; Coates, T.D 26

Fluorescent Laser Scanning Microscopy

Fluorescent Laser Scanning Microscopy of F-Actin Disruption

in Human Endometrial Stromal Cells Expressing the SV40

Large T Antigen and the EJ ras Oncogene

Carter, C.A.; Rinehart, C.A.; Bagnell, C.R., Jr.; Kaufman,

D.G 36

c-erbB-2 Expression

Expression of c-erbB-2 in Human Pancreatic Adenocarcino-mas (With 1 color plate)

Williams, T.M.; Weiner, D.B.; Greene, M.I.; Maguire,

H.C., Jr 46

Hematopoietic Clonal Assays

Utility of Human Bone Marrow Obtained Incidental to Or

thopedic Surgery for Hematopoietic Clonal Assays

Volpe, D.A.; Du, D.-L.; Pohl, K.P.; Campbell, J.P.; Mur

phy, M.J., Jr 53

Erratum $\quad 56$

No. 2

Antigen Sites by Flow Cytometry

Enumeration of Antigen Sites on Cells by Flow Cytometry

Dawson, CD.; Scheppler, J.A.; Nicholson, J.K.A.; Hol-

man, R.C 57

DNA Ploidy and Cytokeratin Patterns

Correlation of DNA Ploidy Levels with Altered Cytokeratin

Patterns in Rat Bladder Tumors

Reedy, E.A.; Cottrell, J.R.; Resau, J.H 62

Chemically Induced Neoplastic Transformation

Inhibition of Chemically Induced Neoplastic Transformation

in vitro by Saturated Fatty Acid

Embleton, M.J.; Noy, R.J 69

Esophageal Carcinoma Cell Line

Characterization of Human Esophageal Carcinoma Cell Line Established on Confluent

Monolayer, and Advantage of Confluent Monolayer Surface Structure for Attachment and

Growth Matsuoka, H; Mori, M.; Ueo, H; Sugimachi, K.; Urabe, A. 76

IV

Contents

Hypercholesterolemia and Atherosclerosis 
Effects of Low-Density Lipoprotein from Normal Rabbits on Hypercholesterolemia and the Development of Atherosclerosis

Kanazawa, T.; Tanaka, M.; Fukushi, Y.; Onodera, K.; Lee,

K.T.; Metoki, $\mathrm{H} \quad 85$

Macrophages in Atherosclerosis

Reappraisal of the Role of Macrophages in the Pathogenesis of

Atherosclerosis

Wolman, M.; Gaton, E 92

Antisurfactant Antibodies

Effects of Antisurfactant Antibodies on the Course of Mild Respiratory Distress Syndrome

Eijking, E.P.; Strayer, D.S.; van Daal, G.J.; Lachmann, B. 96

AIMS/GRXП Cell Line

Morphological and Functional Characterization of a Hormon-

ally Induced AIMS/GRXП Cell Line

Chapekar, T.N.; Sharma, N.; Malik, A.K 102

Proteolytic Degradation of Desquamin

Sensitivity of Desquamin to Proteolytic Degradation

Brysk, M.M.; Bell, T.; Rajaraman, S 109

No. 3

The Macrophage 1990. Part I

Macrophage Heterogeneity and Differentiation

Influence of Interleukin-2 on the Differentiation of Macrophages Lohmann-Matthes, M.-L.;

Emmendoerffer, A.; Hao, L. .117

Differentiation of Human Monocytes into CD 14 Negative Accessory Cells: Do Dendritic Cells

Derive from the Monocytic Lineage?

Peters, J.H.; Ruppert, J.; Gieseler, R.K.H.; Najar, H.M.;

$\mathrm{Xu}, \mathrm{H} 122$

Small (CD 14+/CD16+) Monocytes and Regular Monocytes in Human Blood

Ziegler-Heitbrock, H.W.L.; Ströbel, M.; Fingerle, G.; Schlunck, T.; Pforte, A.; Blumenstein, M.;

Haas, J.G. . . 127

Cytokine Regulation of the Myeloid Glycoprotein CD 14

Landmann, R.; Wesp, M.; Obrecht, J.P 131

Synthesis of Complement Components $\mathrm{C} 2$ and $\mathrm{C} 4$ by Human

Monocyte-Derived Macrophages during in vitro Differen

tiation in Serum-Free Culture Conditions

Vincent, F.; Eischen, A.; de la Salle, H.; Bergerat, J.P.;

Faradji, A.; Hauptman, G.; Oberling, F 136

Selected Abstracts $\quad 140$

Macrophages in the Pathogenesis of Disease

New Insights into the Immunopathology of Tuberculosis

Rook, G.A.W.; Al Attiyah, R.; Filley, E 148

The Macrophage in Tuberculosis: Sinner or Saint? The T Cell

Decides

Kaufmann, S.H.E 153 
Phagocytosis and Heat Shock Response in Human Monocytes-

Macrophages

Donati, Y.R.A.; Kantengwa, S.; Polla, B.S 156

Intracellular Pathogens and Professional Phagocytes in Reactive Arthritis Wuorela, M.; Jalkanen, S.; Toivanen, P.; Granfors, K. . . 162

Activation of Monocytes during Inflammatory Bowel Disease

Andus, T.; Gross, V.; Cäsar, I.; Krumm, D.; Hosp, J.; David,

M.; Schölmerich, J 166

Low Incidence of Transplant-Related Complications in Patients with Chronic Release of Tumor Necrosis Factor-Alpha before Admission to Bone Marrow Transplantation: A Clinical Correlate of Cytokine Desensitization? Holler, E.; Hintermeier-Knabe, R.; Kolb, H.J.; Kempeni, J.; Möller, A.; Liesenfeld, S.; Daum, L.; Wilmanns, W. . 171

Selected Abstracts 176

Macrophages and Antimicrobial Defense

Tumor Necrosis Factor-Alpha: Central Regulatory Cytokine in the Induction of Macrophage

Antimicrobial Activities Nacy, C.A.; Meierovics, A.I.; Belosevic, M.; Green, S.J. . 182

Regulatory Mechanisms of Host Responsiveness to Endotoxin

(Lipopolysaccharide)

Mathison, J.; Tobias, P.; Wolfson, E.; Ulevitch, R 185

Microbicidal Activities of Salmonella typhimurium- and Inter-

feron-Gamma-Activated Mouse Peritoneal Macrophages

Langermans, J.A.M.; Nibbering, P.H.; van der Hulst,

M.E.B.; van Furth, R 189

Formation of Interferon-Gamma and Tumor Necrosis Factor

in Mice during Salmonella typhimurium Infection

Kumazawa, Y.; Freudenberg, M.A.; Hausmann, C; Meding-

Slade, S.; Langhorne, J.; Galanos, C 194

Lipopolysaccharide-Instructed, Cryopreserved, Human Mono

cytes Sequentially Convert Plasma Fibrinogen to Fibrin

and Lyse the Fibrin Formed

Kierulf, P.; Andersen, Á.-B.W

Selected Abstracts $\quad 200$

No. 4

The Macrophage 1990. Part II

Macrophage and Viral Infection

Regulation of Cytokine and Viral Gene Expression in Mono

cytes Infected with the Human Immunodeficiency Virus

Meltzer, M.S.; Baca, L.; Turpin, J.A.; Kalter, D.C.; Dief-

fenbach, C; Friedman, R.M.; Gendelman, H.E 209

Contents

$\mathrm{V}$

AIDS Encephalopathy and Tropism of HIV for Brain Monocytes/Macrophages and Microglial Cells

Vazeux, R 214

Secretory Repertoire of HIV-Infected Human Monocytes/ Macrophages 
Esser, R.; von Briesen, H.; Brugger, W.; Ceska, M.;

Glienke, W.; Müller, S.; Rehm, A.; Rübsamen-Waigmann,

H.; Andreesen, R 219

Interaction of Cultured Human Kupffer Cells with HIV-

Infected CEM Cells: An Electron Microscopic Study

Gendrault, J.L.; Steffan, A.M.; Schmitt, M.P.; Jaeck, D.;

Aubertin, A.M.; Kirn, A 223

Influenza A Virus Infects Macrophages and Stimulates Release of Tumor Necrosis Factor-Alpha

Hinder, F.; Schmidt, A.; Gong, J.-H.; Bender, A.; Sprenger,

H; Nain, M.; Gemsa, D 227

Regulation by Endogenous Interferon of Virus-Induced Cyto-

kine Gene Expression in Mouse Macrophages

Zawatzky, R.; Homfeld, A 232

Selected Abstracts 237

Macrophages as Tumor Cytotoxic Effector Cells

The Role of Macrophages in the Regulation of Primary Tumor

Growth

Walter, S.; Govoni, D.; Bottazzi, B.; Mantovani, A. ... 239 Monocyte-Mediated Growth Control and the Induction of

Tumor Cell Death

van der Bosch, J.; Rüller, S.; Horn, D.; Schlaak, M. ... 243 Tumoricidal Effector Molecules of

Murine Macrophages

Schwamberger, G.; Flesch, I.; Ferber, E 248

Antibody-Mediated Tumor Cytotoxicity of Microglia

Sutter, A.; Hekmat, A.; Luckenbach, G.A 254

Adoptive Immunotherapy with Autologous Macrophages:

Current Status and Future Perspectives

Andreesen, R.; Hennemann, B 259

Treatment of Cancer Patients with Endotoxin Induces Release

of Endogenous Cytokines

Mackensen, A.; Galanos, C; Engelhardt, R 264

Selected Abstracts 268

Macrophage Biochemistry and Molecular Biology

A Membrane-Bound Form of the Acute-Phase Protein C-

Reactive Protein Is the Galactose-Specific Particle Recep

tor on Rat Liver Macrophages

Kolb-Bachofen, V 272

Biochemistry and Function of Pteridine Synthesis in Human and Murine Macrophages

Werner, E.R.; Werner-Feldmayer, G.; Fuchs, D.; Hausen,

A.; Reibnegger, R.; Yim, J.J.; Wachter, H 276

Regulation of Nitric Oxide Production by Stimulated Rat Kupffer Cells Gaillard, T.; Mülsch, A.;

Busse, R.; Klein, H.; Decker, K. 280

Regulation of M-CSF Expression by M-CSF: Role of Protein

Kinase $\mathrm{C}$ and Transcription Factor NFkB

Brach, M.A.; Henschler, R.; Mertelsmann, R.H.; Herr

mann, F 284 
The c-fgr Proto-Oncogene: Expression in Epstein-Barr-VirusInfected B Lymphocytes and in Cells of the Myelomonocytic and Granulocytic Lineages

Patel, M.; Faulkner, L.; Katz, D.R.; Brickell, P.M 289

Increased Methylation of the c-fms Protooncogene in Acute Myelomonocytic Leukemias

Feigner, J.; Kreipe, H.; Heidorn, K.; Jaquet, K.; Zschunke,

F.; Radzun, H.-J.; Parwaresch, M.R 293

Selected Abstracts 299

No. 5

Experimental Allergic Encephalomyelitis

Induction of Experimental Allergic Encephalomyelitis by My-elin Proteolipid-Protein-Specific T

Cell Clones and Synthetic Peptides

Kuchroo, V.K.; Sobel, R.A.; Yamamura, T.; Greenfield, E.;

Dorf, M.E.; Lees, M.B 305

Adenovirus Subtypes Related to NK Cytolysis

Studies of Adenovirus Subtypes and Down-Regulation of HLA

Class I Expression: Correlations to Natural-Killer-Me

diated Cytolysis

Bosse, D.; Ades, E 313

Matrix Proteins

Matrix Proteins Induce Neuroblastoma Cell Differentiation without Altering Cell Growth

Kidowaki, T.; Thiele, C.J.; Kleinman, H.K.; Israel, M.A.. 316

HIV Infection and HLA

HLA Disease Association and Protection in HIV Infection

among African Americans and Caucasians

Cruse, J.M.; Brackin, M.N.; Lewis, R.E.; Meeks, W.;

Nolan, R.; Brackin, B 324

Epidermal Growth Factor Receptor

Density-Dependent Regulation of Epidermal Growth Factor Receptor Expression

Hamburger, A.W.; Mehta, D.; Pinnamaneni, G.; Chen,

L.C.; Reid, Y 329

Mouse Melanoma Cells

Tyrosinase Expression and Melanogenesis in Melanotic and Amelanotic B16 Mouse Melanoma

Cells Burchill, S.A.; Bennett, D.C.; Holmes, A.; Thody, A.J. . . 335

Superoxide Dismutase

Human Recombinant Superoxide Dismutase Protects Primary Cultured Neuron against Hypoxic Injury Kinoshita, A.; Yamada, K.; Kohmura, E.; Hayakawa, T. . 340

VI

Contents

AIMS/GRXIII Cell Line

The AIMS/GRXVIII Cell Line: 'Spontaneous' Transforma

tion of Hormonally Induced Primary Cells Derived from

Goat Ovarian Granulosa

Chapekar, T.N.; Malik, A.K 345

Hepatocyte Spheroid Assembly 
Promotion of Spheroid Assembly of Adult Rat Hepatocytes by Some Factor(s) Present in the Initial 6-Hour Conditioned Medium of the Primary Culture Sakaguchi, K.; Koide, N.; Asano, K.; Takabatake, H.; Matsushima, H.; Takenami, T.; Ono, R.; Sasaki, S.; Mori, M.;

Koide, Y.; Tsuji, T 351

Friedreich's Ataxis

Growth Studies on Fibroblasts of Patients with Autosomal

Recessive Friedreich's Ataxia

Willers, I.; Koeppen, A.; Singh, S.; Goedde, H.W 357

No. 6

Genes Facilitate HIV-1 Infection

Human Genes Other than CD4 Facilitate HIV-1 Infection of Murine Cells Weiner, D.B.;

Huebner, K.; Williams, W.V.; Greene, M.I. 361

Cytokine Alters Lymphocyte Distribution

Cytokine Administration Alters the Distribution of Activated Lymphocytes to the Lung

Dubinett, S.M.; Callahan, R.J.; Xia, W.; Ahmad, M.;

Strauss, H.W.; Kradin, R.L 372

Lipopolysaccharide Endotoxic Activity

Modulation of Endotoxic Activity of Lipopolysaccharide by

High-Density Lipoprotein

Baumberger, C; Ulevitch, R.J.; Dayer, J.-M 378

Differentiation Associated Phosphoproteins

Identification of Two 36-kD Phosphoproteins Associated with

Altered Differentiation in Retrovirus-Transformed

Balb/MK-2 Mouse Keratinocytes

Makino, J.K.; Weissman, B.E384

Suppression of Immunoglobulin Synthesis

Suppression of Human Immunoglobulin Synthesis by Interleu-

kin-4 in Tandem with Interleukin-2 through Large Granu

lar Lymphocytes

Bosse, D.; Ades, E 391

Linear Epitope Identification

Identification of Linear Epitopes of the BPV-1 LI Protein Rec

ognized by Sera of Infected or Immunized Animals

Jenson, A.B.; Lim, P.; Ghim, S.; Cowsert, L.; Olson, C;

Lim, L.-Y.; Farquhar, C; Pilacinski, W 396

Colon Explant Culture

Long-Term Explant Culture of Human Colon and a 3-Step

Transformation Model for Rat Colonic Epithelium

Sakamoto, K.; Resau, J.H.; Shamsuddin, A.M.; Yuasa, Y.;

Hoshino, H.; Nakano, G.; Nagamachi, Y 404

Author Index 412

Subject Index 415 